\title{
New rhizobial strains for velvet bean (Stizolobium aterrimum) evaluated under greenhouse and field conditions
}

\author{
Novas estirpes rizobianas para mucuna preta (Stizolobium aterrimum) \\ avaliadas sob condições de casa de vegetação e campo
}

\author{
Ítalo Augusto Férrer Melo Santos ${ }^{1}$, Mario de Andrade Lira Junior², Adeneide Candido Galdino², \\ Felipe José Cury Fracetto ${ }^{2}$, Giselle Gomes Monteiro Fracetto ${ }^{2 *}$
}

\author{
'Universidade Federal de Lavras/UFLA, Departamento de Biologia/DBI, Lavras, MG, Brasil \\ ${ }^{2}$ Universidade Federal Rural de Pernambuco/UFRPE, Recife, PE, Brasil \\ ${ }^{*}$ Corresponding author: giselle.fracetto@ufrpe.br \\ Received in May 1, 2017 and approved in June 6, 2017
}

\begin{abstract}
The selection of efficient rhizobia for the inoculation of velvet bean may increase the use of this plant as green manure, maximizing the addition of nitrogen $(\mathrm{N})$ to the crop. This study aimed to select rhizobia that nodulate velvet bean more efficiently than do strains currently recommended and for the potential of rhizobia to compose an inoculant. A greenhouse experiment evaluated 39 strains using non-sterile soil and was followed by a field experiment with the five most effective strains under field conditions on a dystrocohesive Yellow Argisol. Both experiments included non-inoculated and inoculated treatments with currently recommended strains and $\mathrm{N}$-fertilized controls. Nodules, root and shoot dry mass, shoot $\mathrm{N}$ concentration and accumulation and relative efficiency were evaluated. The $\mathrm{N}$ dose corresponding to the shoot dry mass increase of the inoculated plants was also estimated. Under field conditions, the plants inoculated with the strains T2.19A and T1.17M had a shoot $\mathrm{N}$ concentration similar to that from the application of $80 \mathrm{~kg} \mathrm{ha}^{-1} \mathrm{~N}$, and the $\mathrm{N}$ concentration was significantly higher that of the other treatments; additionally, the $\mathrm{N}$ accumulation was significantly higher than that of the control (112 and $104 \%$ for the two strains, respectively), the recommended strain mixture inoculation ( 99 and $91 \%$, respectively) and the mineral $\mathrm{N}$ application (58 and $52 \%$, respectively). Inoculation with T2.19A and T1.17M presented promising results, showing the potential of these strains for recommendation and inoculation of velvet bean.
\end{abstract}

Index terms: Green manure; efficient rhizobia; biological nitrogen fixation.

\section{RESUMO}

A seleção de rizóbios eficientes para inoculação em mucuna preta pode aumentar o uso dessa leguminosa como adubo verde, maximizando o incremento de nitrogênio $(\mathrm{N})$ na cultura. O objetivo deste trabalho foi selecionar rizóbios que nodulam mucuna preta com eficiência superior às estirpes atualmente recomendadas, com potencial para compor um inoculante. Um experimento em casa de vegetação avaliou 39 estirpes em solo não esterilizado, seguido de um experimento de campo com as cinco estirpes mais efetivas sob condições de campo em um argisolo amarelo distrocoeso. Ambos os experimentos incluíram a inoculação com as estirpes atualmente recomendadas, sem inoculação e os controles fertilizados com N, avaliando-se assim os nódulos, a massa seca da raiz e da parte aérea, a concentração e acúmulo de $\mathrm{N}$ da parte aérea e eficiência relativa. A dose de $\mathrm{N}$ correspondente ao ganho de massa seca da parte aérea das plantas inoculadas foi também estimada. Em condições de campo, as plantas inoculadas com os isolados T2.19A e T1.17M tiveram concentração de $\mathrm{N}$ na parte aérea similar a aplicação de $80 \mathrm{~kg} \mathrm{ha}^{-1}$ de $\mathrm{N}$ e significativamente superior aos demais tratamentos. Além disso, o acúmulo de $\mathrm{N}$ foi significativamente superior ao controle (112 e 104\%), à inoculação com a mistura das estirpes recomendadas (99 e 91\%) e à aplicação de nitrogênio mineral (58 e 52\%), respectivamente. A inoculação com as estirpes T2.19A e T1.17M apresentou resultados promissores, mostrando o seu potencial para recomendação e inoculação em mucuna preta.

Termos para indexação: Adubo verde; rizóbio eficiente; fixação biológica de nitrogênio.

\section{INTRODUCTION}

Green manuring with legumes improves soil quality and increases available nitrogen by biological nitrogen fixation (BNF) through the symbiotic relationship between rhizobia and legumes. Velvet bean (Stizolobium aterrimum) is recommended for green manuring of several crops due to the high biomass productivity and potential for nitrogen fixation under tropical conditions (Ambrosano et al., 2011, 2013; Andrade Neto et al., 2010; Queiroz et al., 2010; Zaccheo et al., 2016).

Velvet bean is of African origin, with a cycle ranging from 140 to 180 days (Formentini, 2008). Velvet bean is considered an annual or bi-annual legume that requires a warm climate and tolerates low fertility and 
low soil moisture (Eiras; Coelho, 2010). Experiments indicate the shoot dry mass yield is between 6 and $9 \mathrm{Mg} \mathrm{ha}^{-1}$, resulting in up to $350 \mathrm{~kg}$ biologically fixed $\mathrm{N} \mathrm{ha}^{-1}$ per crop (Formentini, 2008), but there is large variation depending on the soil and climatic conditions (Barros; Gomide; Carvalho, 2013).

Biological nitrogen fixation is affected by bacterial, plant and environmental factors. The native rhizobia population of the soil may not be able to perform efficient symbiosis and may compete with the strains introduced in the inoculation, failing to achieve the maximum potential of $\mathrm{N}$ fixation (Soares et al., 2006). Moreover, to inoculate with more efficient rhizobia, it is important to adjust the acidity and soil fertility to favor symbiosis, which consequently increases BNF (Amado; Mielniczuk; Aita, 2002).

There have been few studies under experimental field conditions aiming to select more efficient rhizobia for velvet bean. Chada and De Polli (1988) evaluated the efficiency of strains recommended for velvet bean in the soil and reported that the strains were not more efficient in the presence of native rhizobia. Similarly, Rodrigues, De-Polli and Eira (1994) showed that the inoculation of selected strains of Rhizobium in velvet bean and spontaneous nodulation resulted in the same performance. Therefore, the search for new strains with a greater capacity of nitrogen fixation is extremely necessary.

Thus, we selected rhizobia nodules of velvet bean with higher efficiency than the strains currently recommended have for study under greenhouse and experimental field conditions.

\section{MATERIAL AND METHODS}

\section{Greenhouse conditions}

This experiment was conducted in a completely randomized design with five repetitions for 45 days. Thirty-nine new rhizobial strains; the mixture of two strains currently recommended for commercial inoculant production for velvet bean, SEMIA6156 $=$ CPAC F2 $=$ AY904758 (Bradyrhizobium elkanii) and SEMIA 6158=CPAC $\mathrm{C} 2=\mathrm{AY} 904760$ (B. elkanii); and five non-inoculated treatments that received the equivalent of $60,120,180$ and $240 \mathrm{~kg} \mathrm{~N} \mathrm{ha}^{-1}$ (Brasil, 2011) were evaluated. The new strains under evaluation were selected from sugarcane growing in soils in northeastern Brazil.

The pots contained $2.5 \mathrm{~kg}$ of a non-sterile dystrocohesive Yellow Argisol with medium texture (Alves; Ribeiro, 1994), which has been conventionally used in sugarcane cultivation throughout history. In addition to these treatments, we adopted the following treatments as controls: I-inoculation with the mixture of two strains recommended by the Ministerio da Agricultura Pecuária e Abastecimento (MAPA) -Brazil for velvet bean, Bradyrhizobium spp. (SEMIA6156) and Bradyrhizobium elkanii (SEMIA 6158); III-four nitrogen fertilizations $\left(60,120,180\right.$ and $\left.240 \mathrm{~kg} \mathrm{~N} \mathrm{ha}^{-1}\right)$; and IV-noninoculated and non-fertilized (native) control treatments.

The soil was air-dried and sieved through a 4-mm mesh. Two subsamples were then separated, one for chemical and physical analyses and the other for estimating the native rhizobia population (Table 1). The rhizobia population

Table 1: Chemical, physical and microbiological analyses of the soil under greenhouse and field conditions.

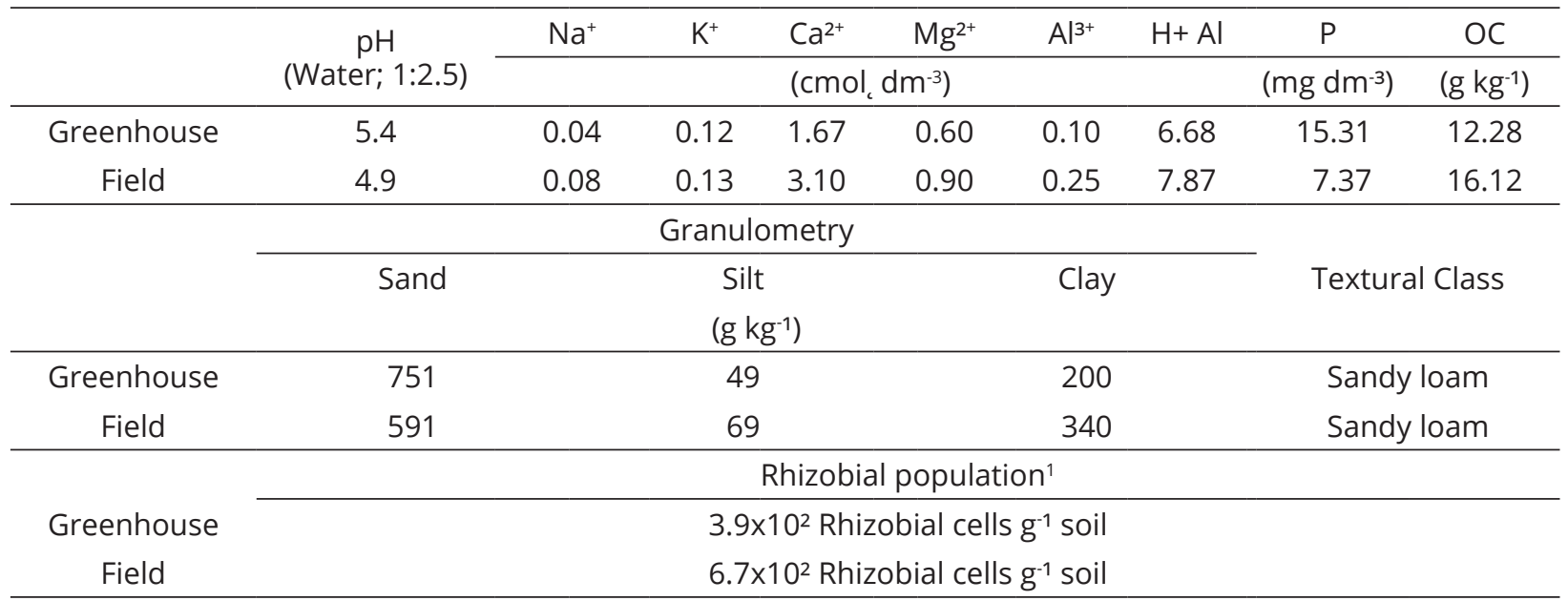

${ }^{1}$ MPN technique of dilution and infection of cowpea plants adapted from Andrade and Hamakawa (1994); chemical and physical analyses, Donagema et al. (1997). OC - Organic carbon. 
determination was performed by the most likely number (MPN) method of dilution and plant infection (Andrade; Hamakawa, 1994). Cowpea plants (Vigna unguiculata (L.) Walp. cv. IPA-206) grown in plastic polyethylene bags containing $500 \mathrm{~g}$ of autoclaved substrate (sand + vermiculite; $1: 1, \mathrm{v}: \mathrm{v})$ were inoculated with $2.0 \mathrm{ml}$ of each soil diluted to $10^{-5}$ and maintained for 45 days, in triplicate.

The soil was adjusted by incorporating dolomitic limestone, calculated by the method of increasing the exchangeable contents of $\mathrm{Ca}+\mathrm{Mg}$ to $2.5 \mathrm{cmol}_{\mathrm{c}} \mathrm{dm}^{-3}$ (Cavalcanti, 2008).

The fertilization application consisted of 53.2 $\mathrm{mg}$ pot $^{-1} \mathrm{P}_{2} \mathrm{O}_{5}$ and $35.5 \mathrm{mg}^{-1} \mathrm{pot}^{-1} \mathrm{~K}_{2} \mathrm{O}$, corresponding to $60 \mathrm{~kg} \mathrm{ha}^{-1}$ and $40 \mathrm{~kg} \mathrm{ha}^{-1}$ doses (Lopes, 2000), using superphosphate and potassium chloride as sources, respectively. For the nitrogen treatment, urea in solution was applied (11.82 $\mathrm{g} \mathrm{L}^{-1}$ of distilled water), divided into three applications $(1 / 3$ of the dose at planting and the other two after 15 and 30 days).

Velvet bean seeds were chemically scarified by immersion in concentrated sulfuric acid for 20 minutes (Maeda; Lago, 1986) followed by washing in distilled water several times. The seeds were pre-germinated in autoclaved sand + vermiculite $(1: 1, \mathrm{v}: \mathrm{v})$ for four days, transplanted and inoculated with $1 \mathrm{ml}$ YMA culture broth containing $10^{9}$ cells $\mathrm{ml}^{-1}$, after counting by repeated dilutions.

Three days after transplanting, shoot, root and nodule dry masses were determined. The shoots were separated at harvest, followed by washing of the root system. The nodules were removed and separately packaged in a paper bag for greenhouse drying at $65^{\circ} \mathrm{C}$ for three days. The following variables were reported: nodule dry mass (NDM), shoot dry mass (SDM) and root dry mass (RDM). Shoot N concentration (SNC) was determined by the Kjeldahl method (Embrapa, 2009), and shoot $\mathrm{N}$ accumulation (SNA) was determined.

Regressions relating SDM, SNC and SNA to the $\mathrm{N}$ doses of non-inoculated plants were used to estimate $\mathrm{N}$ dose. The relative efficiency (RE) of the maximum applied dose of $120 \mathrm{~kg} \mathrm{ha}^{-1}$ was calculated according to the following equation:

$\mathrm{RE}=\left(\frac{\mathrm{SNA} \text { of each treatment }}{\text { SNA of nitrogen treatment with120 } \mathrm{kg} \mathrm{N} \mathrm{ha}^{-1}}\right) \mathrm{X} 100$

The data were submitted to normality analysis and transformed as necessary to conform to ANOVA preconditions. The SNC variable data were square-root transformed, after which ANOVA was performed, and the means were separated by the Scott-Knott test $(\mathrm{p} \leq 0.05)$. Correlations among the variables were evaluated by the Pearson correlation test.

\section{Field conditions}

The experiment was performed at Estação Experimental de Cana-de-Açúcar de Carpina (EECAC/ UFRPE, Pernambuco, Brazil) at $07^{\circ} 35^{\prime} \mathrm{S}, 34^{\circ} 15^{\prime} \mathrm{W}$. The climate is tropical subhumid with a dry summer season. The average yearly rainfall is $1300 \mathrm{~mm} \mathrm{year}^{-1}$, and the average annual temperature is $24{ }^{\circ} \mathrm{C}$. The same soils as those in the greenhouse experiment were used (Table 1).

The area was prepared by heavy disking after the application of dolomitic limestone $\left(0.65 \mathrm{Mg} \mathrm{ha}^{-1}\right)$, which was calculated according to $\mathrm{Al}^{3+}$ neutralization (Cavalcanti, 2008), followed by 60 days before seeding.

Velvet bean was grown in rainfed conditions between May and July 2015 in the rainy season, whose cumulative precipitation was $336.1 \mathrm{~mm}$, for 45 days (IPA - Estação Meteorológica, Pernambuco, Brazil).

The experiment was performed in a randomized block design with four replicates. The five strains selected in the previously described experiment were evaluated; inoculation involved the same recommended strains, and fertilization occurred with $80 \mathrm{~kg} \mathrm{~N}^{-1}$ as urea, with $1 / 3$ applied at seeding and $2 / 3$ applied after 15 days. The plots measured 3.5 by $6.0 \mathrm{~m}\left(21 \mathrm{~m}^{2}\right)$, with $1-\mathrm{m}$ borders between plots. $\mathrm{P}$ and $\mathrm{K}$ fertilization was similar to that of the greenhouse experiment; fertilizer was applied to 3 -cm-deep furrows close to the sowing lines. Seeds were scarified by immersion in hot water at $65{ }^{\circ} \mathrm{C}$ for five minutes (Kobori; Mascarin; Cicero, 2013). Six to eight seeds per meter were hand-seeded in lines spaced $50 \mathrm{~cm}$ apart (Embrapa, 2000) at a 3-cm depth.

Bacterial multiplication and population evaluation followed the same methodology used for the greenhouse experiment. The seeds were moistened in sugar solution (10\%) after overcoming dormancy, and $6 \mathrm{ml} \mathrm{kg}^{-1}$ of seed was added for an adhesive effect. Approximately 700,000 cells of each strain were inoculated separately per seed, relative to $10 \mathrm{~g}$ peat inoculum with a population estimated at $10^{9} \mathrm{CFU} \mathrm{g}^{-1}$ inoculant in $1 \mathrm{~kg}$ seed, with approximately 1400 seeds dried in the shade and sown immediately (Campo et al., 2007).

After 45 days, the plants were harvested, preserving the nodules. Four plants were randomly harvested within the central $10 \mathrm{~m}^{2}$ of each plot. The same variables were determined as those for the greenhouse experiment. The variables NDM and RDM were transformed by the cubic 
root and RE by the first-degree hyperbola. Statistical analysis was performed as described in the greenhouse experiment.

\section{RESULTS AND DISCUSSION}

\section{Greenhouse conditions}

Velvet bean plants responded to increasing $\mathrm{N}$ doses in accordance with a quadratic regression $\left(\mathrm{r}^{2}=0.94\right)$ (Figure 1), with a maximum SDM of $4.28 \mathrm{~g} \mathrm{plant}^{-1}$ with $160 \mathrm{~kg} \mathrm{~N} \mathrm{ha}{ }^{-1}$.

The SNC and SNA concentration increased with increasing urea dose, but phytotoxic effects were observed at $240 \mathrm{~kg} \mathrm{~N} \mathrm{ha}^{-1}$, with SNA reduction (Figure 2) likely due to ammonia formed by the urea hydrolysis (Bremner; Krogmeier, 1988).

Calheiros et al. (2015), evaluating the efficiency of rhizobial strains for calopo (Calopogonium mucunoides), reported influence from increasing doses of $\mathrm{N}$ on SDM, with increased concentration and accumulation of $\mathrm{N}$ in the shoot. Considering the increases in SDM, SNC and SNA and due to the high nitrogen supply to velvet bean, the inoculation of strains with greater $\mathrm{N}_{2}$ fixation capacity may maximize phytomass production and the $\mathrm{N}$ accumulation of the species, as shown in Figures 1 and 2 and Table 2.

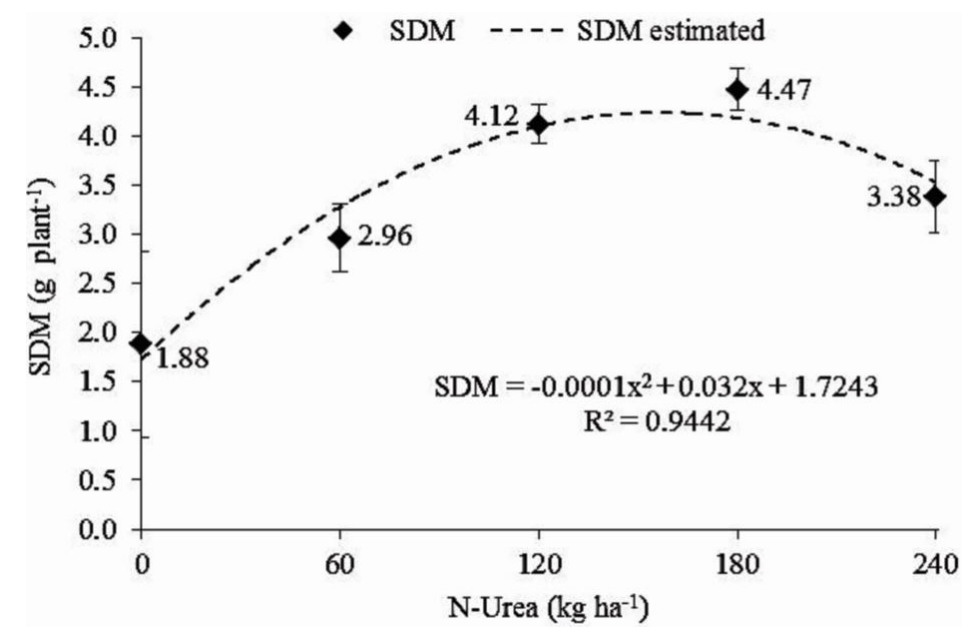

Figure 1: Shoot dry mass (SDM) production of velvet bean according to the $\mathrm{N}$ application in increasing doses $(n=5)$. Vertical bars indicate the standard deviation.

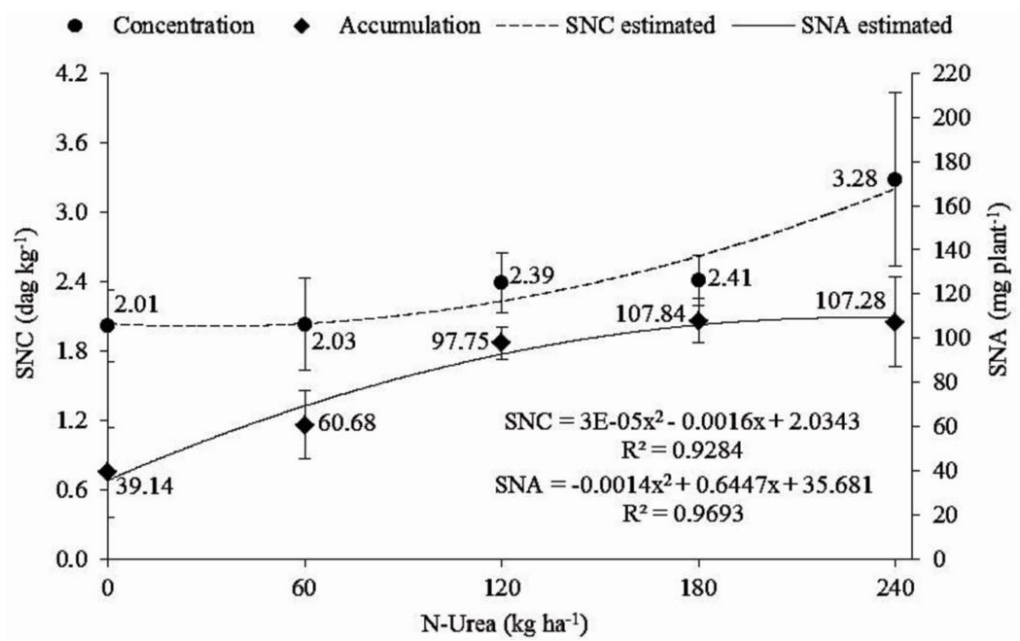

Figure 2: Shoot $N$ concentration (SNC) and shoot $N$ accumulation (SNA) production of velvet bean according to increasing doses of $\mathrm{N}$ application $(n=5)$. Vertical bars represent the standard deviation. 


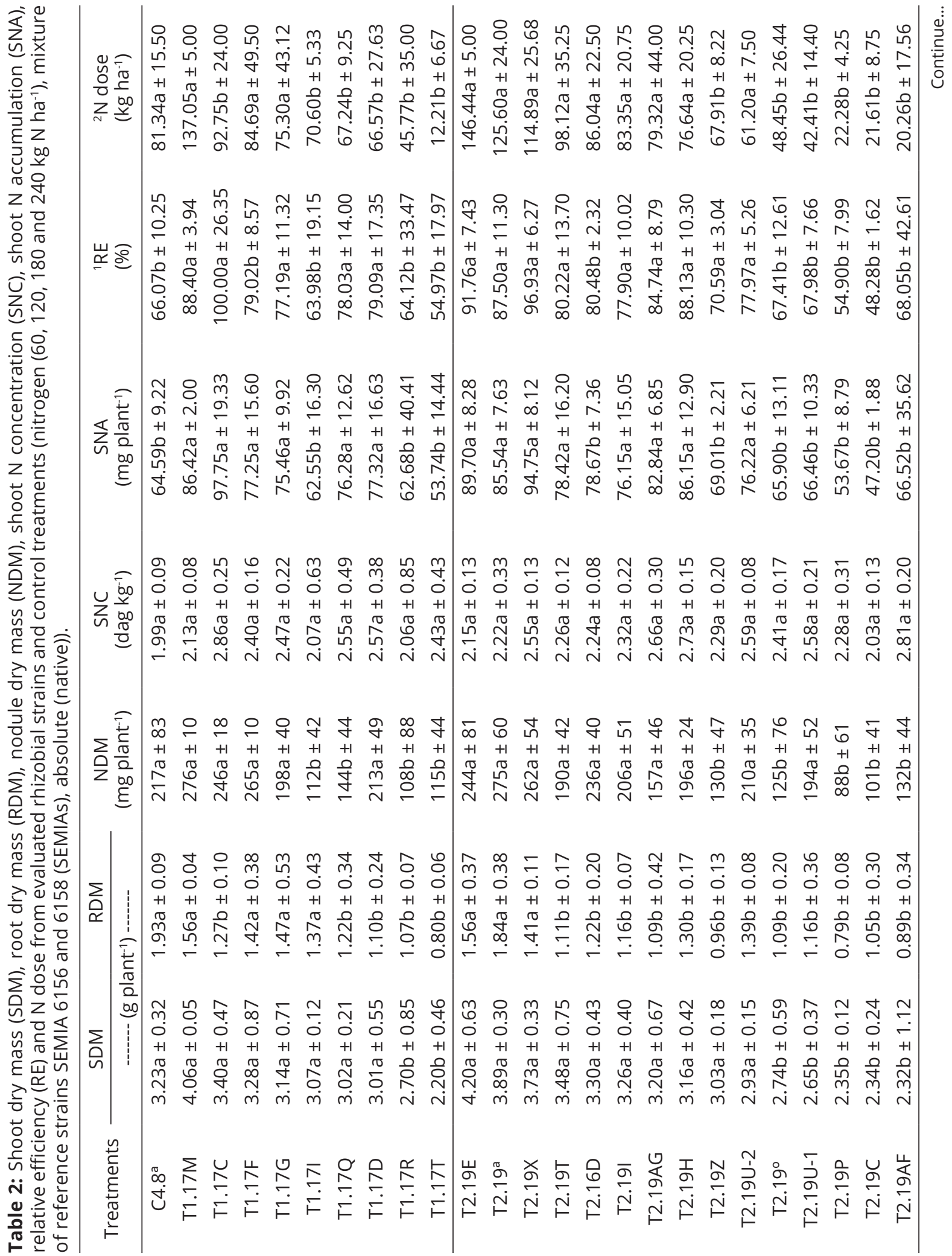




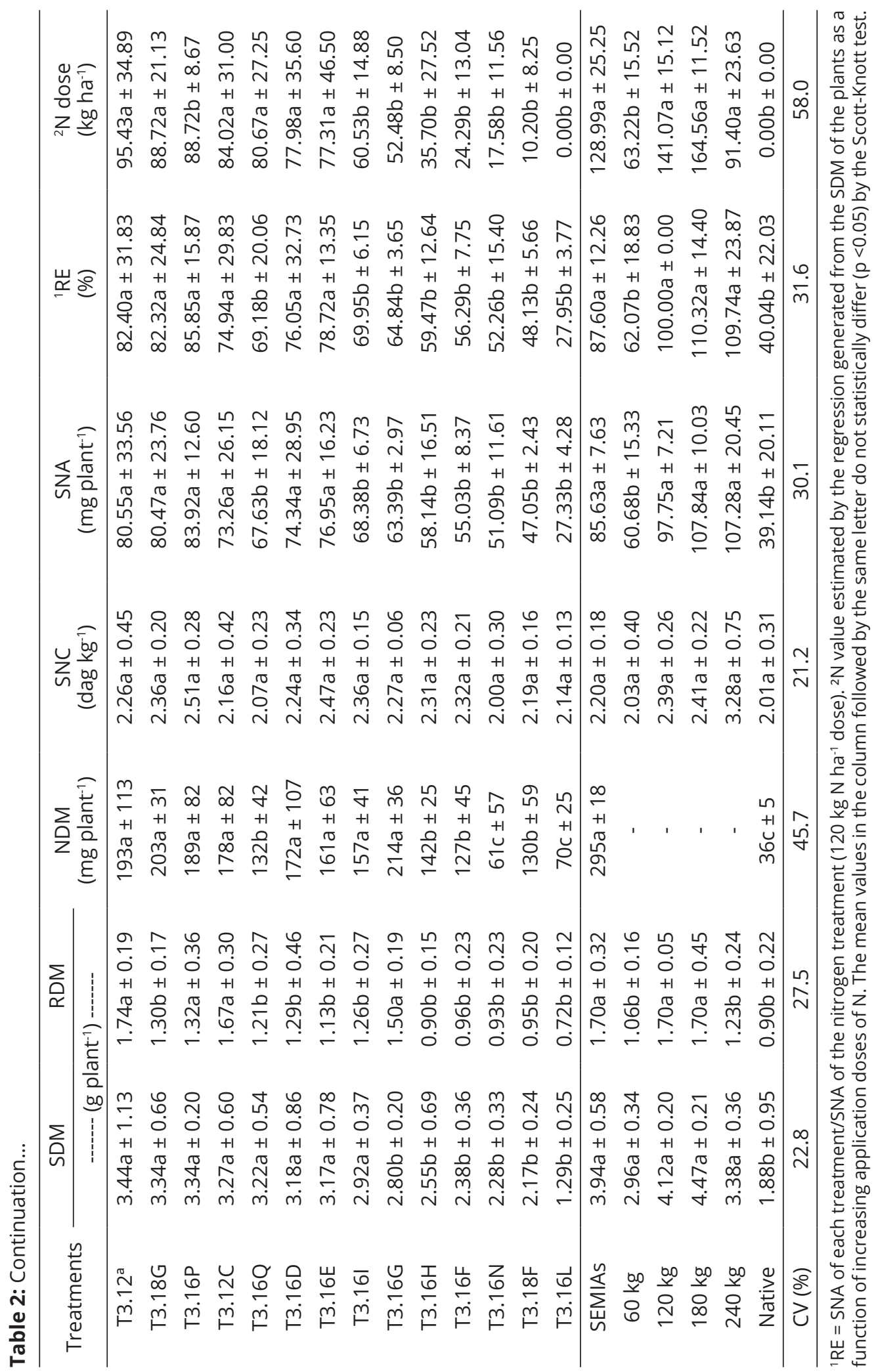


Non-inoculated and non-fertilized plants showed significantly lower nodulation than did plants with both inoculations with the other strains (average $38 \mathrm{mg}$ NDM plant $^{-1}$ ) and the mixture of the recommended strains (SEMIA6156-6158), except strains T3.16 L (70 mg plant $^{-1}$ ) and T3.16N (61 mg plant $\left.{ }^{-1}\right)$, which did not statistically differ (Table 2). These soil conditions indicate that a competing community established in the soil exists with the ability to nodulate velvet bean in low numbers ( 390 cells of rhizobia $\mathrm{g} \mathrm{soil}^{-1}$, as shown in Table 1).

There was no nodulation from any of the applied nitrogen fertilization doses under greenhouse and field conditions, which was also observed by Melo and Zilli (2010) for five cowpea (Vigna unguiculata) plants. Inoculation with all strains promoted a higher SNC than did the native treatment, except for the plants inoculated with $\mathrm{T} 3.16 \mathrm{~N}$ and $\mathrm{C} 4.8 \mathrm{~A}$. In addition, the $\mathrm{SNC}$ of velvet bean inoculated with the tested strains did not differ from that of plants that received the different doses of $\mathrm{N}$, including the highest dose $\left(240 \mathrm{~kg} \mathrm{~N} \mathrm{ha}^{-1}\right)$, and still did not differ significantly from that of plants inoculated with the reference strains.

There was a wide range of NDM values from strains that ranged from 61 to $276 \mathrm{mg} \mathrm{NDM} \mathrm{plant}^{-1}$ (Table 2). The results from inoculation with T1.17M (276 mg plant $\left.{ }^{-1}\right)$, T2.19A (275 mg plant $\left.{ }^{-1}\right)$, T1.17F (265 mg plant $\left.^{-1}\right)$, T2.19X (262 $\left.\mathrm{mg} \mathrm{plant}^{-1}\right)$ and T2.19E (244 mg plant $\left.{ }^{-1}\right)$ did not differ from those with inoculation with the recommended strains (295 mg plant ${ }^{-1}$ ) and were significantly higher than those of SNC. However, increased nodulation was not always associated with increased SDM production and SNC, as reported by Rodrigues et al. (1994), who tested Rhizobium strains in velvet bean and jack bean (Canavalia ensiformis).

We observed that 26 of the 39 strains showed similar SDM values as did the $240 \mathrm{~kg} \mathrm{~N}^{-1}$ and recommended strains mixture treatments. The five most efficient strains were T2.19E, T1.17 M, T2.19A, T2.19X and T2.19T, with SDM productions of 4.20, 4.06, 3.89, 3.73 and 3.48 g plant $^{-1}$, respectively (Table 2 ). The two most efficient strains promoted $6.6 \%$ and $3.1 \%$ accumulation of SDM in this mixture, even though there was no significant difference for inoculation with the recommended strains. Regarding the native treatment, the increases in SDM promoted by these two strains were $123.4 \%$ and $115.9 \%$, which shows the importance of inoculation in velvet bean with more efficient rhizobia.

The SDM in soils with low $\mathrm{N}$ content and in the absence of nitrogen fertilizers represents a major indicator of soybean nutritional conditions (Souza et al., 2008).
Thus, the five strains that showed the highest values were selected for the field agronomic efficiency tests.

The RDM showed both a significant difference and higher values associated with treatments that also presented higher SDM production, except for the T3.16G strain. The same effect on RDM production was also observed by Chagas Júnior et al. (2014) in cowpea.

According to Gray and Smith (2005), the existence of some rhizobia species that promote plant growth may explain the significant production of RDM promoted by the inoculation of some strains that produce growth regulators. These species of rhizobia are also responsible for increased root development in plants of other species of mucuna (Mucuna pruriens (L.) DC. and Mucuna deeringiana (Bort.) Merr.), according to Lima et al. (2012).

The SNC was the only variable in which the effect of the treatments did not present a significant difference according to the Scott-Knott test (Table 2), even with significantly higher NDM for some strains. The values were similar to those reported by Ambrosano et al. (2013).

The same strains that presented higher SNA were also those that achieved the highest RE (\%) (i.e., 100.0, 96.9, 91.7, 88.4, and 88.1) but did not differ statistically among themselves. Only the strain T3.16L (27.5\%) presented lower $\mathrm{RE}$ values than did the native treatment (40.0\%).

With respect to the $\mathrm{N}$ dose required to correspond to the biologically fixed $\mathrm{N}$, the strains that stood out in providing the highest doses were the same ones that presented the highest SDM production: T2.19E, T1.17M, T2.19A, T2.19X and T2.19T, with doses estimated at $146.4,137.0,125.6,114.8$ and $98.1 \mathrm{~kg} \mathrm{ha}^{-1}$, respectively. These same strains produced higher doses of fertilized nitrogen $\left(60 \mathrm{~kg} \mathrm{ha}^{-1}\right)(2.3,2.2,1.9,1.8$ and 1.6 times more, respectively) that were also higher than that of the native treatment, which resulted in low SDM.

Pearson's correlation was positive for most of the variables except for the SNC variable in relation to the RDM. The high correlation coefficients between the SNA and the both SDM and ER variables are highlighted, at 81.7 and $96.7 \%$, respectively. In addition, the correlation coefficient of the SDM was $94.0 \%$.

\section{Field conditions}

In relation to NDM, RDM, SDM and RE variables, there was no significant difference in inoculation with each of the five selected strains in the greenhouse (Table 3). The non-inoculated and non-fertilized plants presented similar nodulation as that of all treatments with an estimated population of 670 rhizobia cells per gram of soil (Table 1) 
and an NDM of $1.62 \mathrm{~g} \mathrm{plant}^{-1}$ (Table 3 ). This result shows that a population of symbionts native to velvet bean has been established in low population numbers but has a high symbiotic efficiency. The nitrogen fertilizer treatment had an NDM of $1.52 \mathrm{~g} \mathrm{plant}^{-1}$ (Table 3 ), which was not different from the non-fertilized NDM, even with the application of the $80 \mathrm{~kg} \mathrm{~N}^{-1}$ as urea.

The strain T2.19A presented the highest NDM (3.11 g plant $\left.^{-1}\right)$. This value was 2.0, 1.9 and 1.5 times higher than that of the nitrogen control treatment $\left(80 \mathrm{~kg} \mathrm{ha}^{-1}\right)$, the non-inoculated and non-fertilized (native) treatment and the inoculation with the mixture of two reference strains (SEMIA6156-6158) treatment, respectively.

The strains T2.19A and T1.17M presented higher performance than did the others, with SDM productions of 44.03 and $40.16 \mathrm{~g} \mathrm{plant}^{-1}$, respectively. These results show the importance of inoculation with more efficient strains in the biological nitrogen fixation for velvet bean.

The non-inoculated and non-fertilized treatment presented lower results than those reported by Favero et al. (2000) and Teodoro et al. (2009). This finding is due to the early plant harvesting at 45 days. However, inoculation with the selected strains promoted a high production of SDM and $\mathrm{N}$ accumulation, specifically for strains T2.19A and T1.17M, which promoted both 5.6 and $5.1 \mathrm{tha}^{-1}$ and accumulations of 135.1 and $113.8 \mathrm{~kg} \mathrm{~N} \mathrm{ha}^{-1}$, respectively, which were similar to the values reported by Formentini (2008). In addition to the inoculation with more efficient rhizobia, fertilization favored higher yields in less cultivation time.

The strains T2.19A and T1.17M were promising for inoculation in velvet bean because their performance was superior to that of the native treatment and the mixture of strains SEMIA 6156-6158. There was a significant difference among the treatments for the SNC variable; plants inoculated with the strains T2.19A and T1.17M differed significantly from plants inoculated with the other strains tested and from those with inoculated with mixture of strains.

In relation to SNA, the strains T2.19A and T1.17M had the highest performance, with accumulations of 1066.25 mg plant ${ }^{-1}\left(135.1 \mathrm{~kg} \mathrm{ha}^{-1}\right)$ and 1025.85 (113.8 $\left.\mathrm{kg} \mathrm{ha}^{-1}\right)$, respectively (Figure 3 ). There was a mean increase in $\mathrm{N}$ promoted by the inoculation with strains $\mathrm{T} 2.19 \mathrm{~A}$ and $\mathrm{T} 1.17 \mathrm{M}$ in relation to the native treatment, highlighting that the higher accumulation of $\mathrm{N}$ in the shoot is also associated with a higher production of SDM.

According to Giller (2011), 70\% of the $\mathrm{N}$ accumulated in velvet bean comes from BNF. Thus, we can estimate that the mean increases in $\mathrm{N}$ from $\mathrm{BNF}$ due to the inoculation of the T2.19A strain were 50.0, 46.9 and $34.7 \mathrm{~kg} \mathrm{ha}^{-1}$ and for the $\mathrm{T} 1.17 \mathrm{M}$ strain were $35.1,32.0$ and $19.7 \mathrm{~kg} \mathrm{ha}^{-1}$ compared to those of the native treatment, inoculation with the reference strain mixture treatment and nitrogen fertilization treatment, respectively.

Table 3: Nodule dry mass (NDM), root dry mass (RDM), shoot dry mass (SDM), shoot N concentration (SNC), shoot $\mathrm{N}$ accumulation (SNA) and relative efficiency (RE) of five rhizobial strains evaluated in the field and treatments with nitrogen fertilization ( $80 \mathrm{~kg} \mathrm{~N} \mathrm{ha}^{-1}$ ), inoculation of reference strain mixtures SEMIA 6156 and 6158 (SEMIAs) and non-inoculated and non-fertilized controls (native).

\begin{tabular}{|c|c|c|c|c|c|c|}
\hline \multirow{2}{*}{ Treatment } & NDM & RDM & SDM & \multirow{2}{*}{$\begin{array}{c}\text { SNC } \\
(\text { dag kg-1) }\end{array}$} & \multirow{2}{*}{$\begin{array}{c}\text { SNA } \\
\left(\mathrm{mg} \mathrm{plant}^{-1}\right)\end{array}$} & \multirow{2}{*}{$\begin{array}{l}{ }^{1} \mathrm{RE} \\
(\%)\end{array}$} \\
\hline & & \multicolumn{2}{|c|}{ (g plant $\left.^{-1}\right)$} & & & \\
\hline T2.19A & $3.11 \mathrm{a} \pm 1.85$ & $0.99 a \pm 0.08$ & $44.03 a \pm 3.41$ & $2.42 \mathrm{a} \pm 0.31$ & $1066.25 a \pm 140.03$ & $164.70 \mathrm{a} \pm 45.35$ \\
\hline $\mathrm{T} 1.17 \mathrm{M}$ & $1.79 a \pm 0.09$ & $1.17 a \pm 0.18$ & $40.16 a \pm 9.54$ & $2.29 a \pm 0.09$ & $1025.84 a \pm 206.35$ & $140.82 a \pm 49.74$ \\
\hline $\mathrm{T} 2.19 \mathrm{E}$ & $1.91 \mathrm{a} \pm 0.28$ & $1.10 \mathrm{a} \pm 0.23$ & $37.65 a \pm 1.77$ & $1.93 b \pm 0.24$ & $729.38 b \pm 112.05$ & $113.26 a \pm 28.72$ \\
\hline T2.19X & $1.77 a \pm 0.84$ & $1.05 a \pm 0.14$ & $37.95 a \pm 7.10$ & $1.88 \mathrm{~b} \pm 0.24$ & $694.96 b \pm 55.12$ & $114.49 a \pm 3.99$ \\
\hline T2.19T & $2.12 \mathrm{a} \pm 1.01$ & $1.04 a \pm 0.06$ & $36.36 a \pm 8.95$ & $1.62 b \pm 0.15$ & $573.63 b \pm 94.27$ & $83.31 \mathrm{a} \pm 1.71$ \\
\hline SEMIAs & $2.06 a \pm 0.33$ & $1.06 a \pm 0.14$ & $34.63 a \pm 6.02$ & $1.52 b \pm 0.21$ & $537.26 b \pm 134.45$ & $87.63 a \pm 18.52$ \\
\hline $80 \mathrm{~kg}$ & $1.52 \mathrm{a} \pm 1.34$ & $0.85 a \pm 0.06$ & $32.14 a \pm 5.49$ & $2.12 a \pm 0.21$ & $675.87 b \pm 104.86$ & $100.00 a \pm 0.00$ \\
\hline native & $1.62 \mathrm{a} \pm 0.44$ & $1.01 \mathrm{a} \pm 0.23$ & $28.69 a \pm 2.65$ & $1.78 b \pm 0.25$ & $502.93 \mathrm{~b} \pm 31.98$ & $83.49 a \pm 8.90$ \\
\hline VC (\%) & 68.7 & 22.5 & 22.9 & 15.0 & 25.8 & 30.2 \\
\hline
\end{tabular}

${ }^{1} \mathrm{RE}=\mathrm{SNA}$ of each treatment/SNA of the nitrogen treatment ( $\left.80 \mathrm{~kg} \mathrm{ha}^{-1} \mathrm{dose}\right)$. The mean values in the column followed by the same letter do not statistically differ $(p<0.05)$ by the Scott-Knott test. 


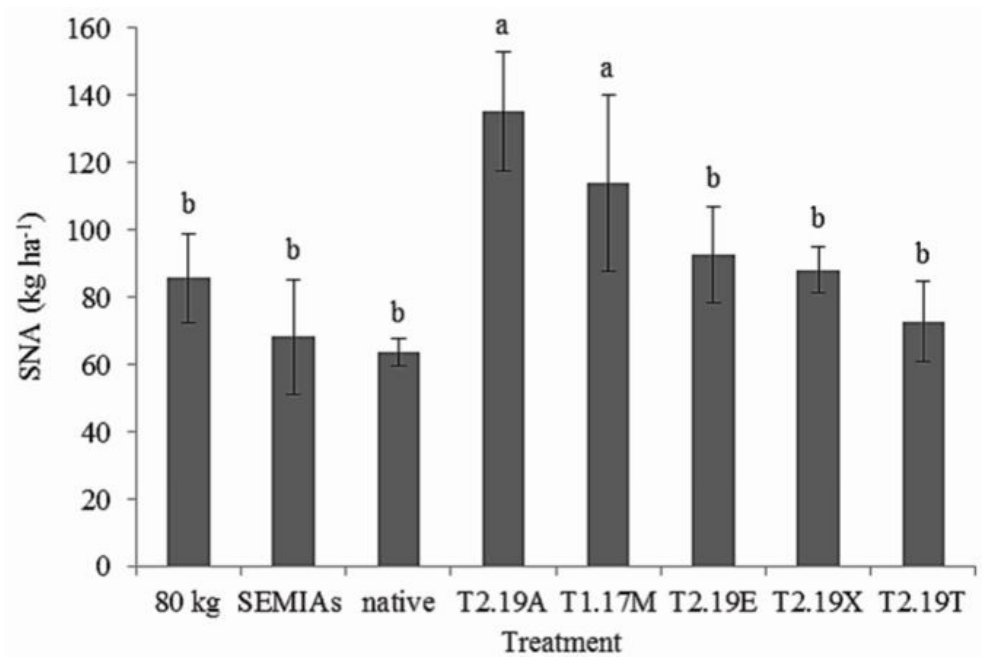

Figure 3: Shoot $\mathrm{N}$ accumulation (SNA) $\left(\mathrm{kg} \mathrm{ha}^{-1}\right)$ of velvet bean plants after 45 days of cultivation inoculated with a mixture of two strains recommended by MAPA for the species (SEMIA 6156-6158), inoculated with five rhizobial strains preselected in the greenhouse, and receiving mineral $\mathrm{N}$ application $\left(80 \mathrm{~kg} \mathrm{ha}^{-1}\right)$ in the urea form as well as native controls (non-inoculated and non-fertilized with mineral $\mathrm{N}$ ). Values followed by the same letter do not significantly differ by the Scott-Knott test at 5\%. Vertical bars represent the standard deviation.

For RE, there was no significant difference among treatments, although the same strains that presented significantly higher MSPA production also had a higher RE, $164.7 \%$ (T2.19A) and 140.8\% (T1.17M), compared to that of fertilization with $80 \mathrm{~kg} \mathrm{~N} \mathrm{ha}{ }^{-1}$. However, the strains T2.19A and T1.17M showed potential biological nitrogen fixation both in the greenhouse and in the field, promoting high SDM production and $\mathrm{N}$ accumulation in less time of legume cultivation, showing the importance of the species for use in green manuring.

Thus, we recommended inoculation of velvet bean with efficient rhizobia, indicating the potential use of this legume as green fertilizer and the benefit of its insertion in crops with rotation and succession. However, more study is needed considering different soil-climatic conditions and longer cultivation times to better evaluate the symbiotic potential of these strains.

\section{CONCLUSION}

Strains T2.19A and T1.17M were promising in velvet bean, indicating their potential use as green manure.

\section{ACKNOWLEDGMENTS}

We thank the Conselho Nacional de Desenvolvimento Científico e Tecnológico (CNPq, Brasília, Brazil), the Coordenação de Aperfeiçoamento de Pessoal de Nível
Superior (CAPES, Brasília, Brazil) and the Fundação de Amparo à Ciência e Tecnologia de Pernambuco (FACEPE, Pernambuco, Brazil) for fellowships. We appreciate all the professionals of the Estação Experimental de Cana-deAçúcar (Carpina-PE/Brazil) and the Universidade Federal Rural de Pernambuco (Recife, Brazil) for their assistance in the field experiment and technical help.

\section{REFERENCES}

ALVES, A. J. de O.; RIBEIRO, M. R. Classificação e aptidão agrícola dos solos da Estação Experimental de Canade-açúcar de Carpina. Aracaju, SE: Embrapa Tabuleiros Costeiros/CPATC, 1994. p.35-55.

AMADO, T. J. C.; MIELNICZUK, J.; AITA, C. Recomendação de adubação nitrogenada para o milho no RS e SC adaptada ao uso de culturas de cobertura do solo, sob sistema plantio direto. Revista Brasileira de Ciência do Solo, 26(1):241-248, 2002.

AMBROSANO, E. J. et al. Produtividade da cana-de-açúcar após o cultivo de leguminosas. Bragantia, 70(4):810$818,2011$.

AMBROSANO, E. J. et al. Acúmulo de massa e nutrientes por adubos verdes e produtividade da cana-planta cultivada em sucessão, em duas localidades de São Paulo, Brasil. Revista Brasileira de Agroecologia, 8(1):199-209, 2013. 
ANDRADE NETO, R. C. et al. Crescimento e produtividade do sorgo forrageiro BR 601 sob adubação verde. Revista Brasileira de Engenharia Agrícola e Ambiental, 14(2):124-130, 2010.

ANDRADE, D. S.; HAMAKAWA, P. J. Estimativa do número de células viáveis de rizóbio no solo e em inoculantes por infecção em plantas. In: HUNGRIA, M.; ARAÚJO, R. $S$. Manual de métodos empregados em estudos de microbiologia agrícola. Brasília, DF: EMBRAPA/CNPAF, 1994. p.63-94. (Documentos, 46).

BARROS, D. L.; GOMIDE, P. H. O.; CARVALHO, G. J. de. Plantas de cobertura e seus efeitos na cultura em sucessão. Bioscience Journal, 29(2):308-318, 2013.

BRASIL. Ministério da Agricultura, Pecuária e Abastecimento. Instrução normativa $\mathbf{n}^{\circ}$ 13. Diário Oficial da República Federativa do Brasil, 2011. Seção 1, p.3-7.

BREMNER, J. M.; KROGMEIER, M. J. Elimination of the adverse effects of urea fertilizer on seed germination, seedling growth, and early plant growth in soil. Proceedings of the National Academy of Sciences, 85(13):4601-4604, 1988.

CALHEIROS, A. S. et al. Symbiotic effectiveness and competitiveness of calopo rhizobial strains in an argissolo vermelho-amarelo under three vegetation covers in the dry forest zone of Pernambuco. Revista Brasileira de Ciência do Solo, 39(2):367-376, 2015.

CAVALCANTI, F. J. de A. Recomendações de adubação para o Estado de Pernambuco: Segunda aproximação. Recife: IPA, 2008. 212p.

CHADA, S. de S.; DE POLLI, H. Nodulação de leguminosas tropicais promissoras para adubação verde em solo deficiente em fósforo. Pesquisa Agropecuária Brasileira, 23(11):1197-1202, 1988.

CHAGAS JÚNIOR, A. F. et al. Promoção de crescimentos em feijão-caupi inoculado com rizóbio e Trichoderma spp. no cerrado. Revista Caatinga, 27(3):190-199, 2014.

DONAGEMA, G. K et al. Manual de métodos de análises de solo. Rio de Janeiro: EMBRAPA/CNPS, 1997. 212p.

EIRAS, P. P.; COELHO, F. C. Adubação verde na cultura do milho. Niterói, RJ: Programa Rio Rural, 2010. 24p. (Manual Técnico, 28).

EMPRESA BRASILEIRA DE PESQUISA AGROPECUÁRIA - EMBRAPA. Mucuna preta Stizolobium aterrimum Piper \& Tracy leguminosa para adubação verde do solo e alimentação de bovinos. Recomendação Técnica No 15. Embrapa Amazônia Oriental, Altamira, Pará, 2000. Available in: <https:// www.embrapa.br/amazonia-oriental/busca-de-publicacoes/-/ publicacao/854699/mucuna-preta-stizolobium-aterrimumpiper--tracy-leguminosa-para-adubacao-verde-do-solo-ealimentacao-de-bovinos>. Access in: 12/04/2017.

EMPRESA BRASILEIRA DE PESQUISA AGROPECUÁRIA EMBRAPA. Manual de análises químicas de solos, plantas e fertilizantes. Brasília, DF: Embrapa Informação Tecnológica, 2009. 627p.

FAVERO, C. et al. Crescimento e acúmulo de nutrientes por plantas espontâneas e por leguminosas utilizadas para adubação verde. Revista Brasileira de Ciência do Solo, 24(1):171-177, 2000

FORMENTINI, E. A. et al. Cartilha sobre adubação verde e compostagem. Vitória: INCAPER, 2008. 27p.

GILLER, K. E. Nitrogen fixation in tropical cropping systems. In: TEODORO, R. B. et al. Aspectos agronômicos de leguminosas para adubação verde no Cerrado do Alto Vale do Jequitinhonha. Revista Brasileira de Ciência do Solo, 35(2):635-643, 2011.

GRAY, E. J.; SMITH, D. L. Intracellular and extracellular PGPR: Commonalities and distinctions in the plant-bacterium signaling processes. Soil Biology and Biochemistry, 37(3):395-412, 2005.

KOBORI, N. N.; MASCARIN, G. M.; CICERO, S. M. Métodos não sulfúricos para superação de dormência de sementes de mucuna-preta (Mucuna aterrima). Informativo ABRATES, 23(1):25-32, 2013

LIMA, A. A. de et al. Diversidade e capacidade simbiótica de rizóbios isolados de nódulos de Mucuna-Cinza e Mucuna-Anã. Revista Brasileira de Ciência do Solo, 36(2):337-348, 2012.

LOPES, O. M. N. Mucuna preta (Stizolobium aterrimum Piper \& Tracy): Leguminosa para adubação verde do solo e alimentação de bovinos. Altamira, PA: Embrapa Amazônia Oriental, 2000. 3p. (Recomendação Técnica, 15).

MAEDA, J. A. A.; LAGO, A. A. do. Germinação de sementes de mucuna-preta após tratamentos para superação da impermeabilidade do tegumento. Revista Brasileira de Sementes, 8(1):79-84, 1986.

MELO, S. R. de; ZILLI, J. E. Fixação biológica de nitrogênio em cultivares de feijão-caupi recomendadas para o Estado de Roraima. Pesquisa Agropecuária Brasileira, 44(9):11771183,2010 
MINISTÉRIO DA AGRICULTURA, PECUÁRIA E ABASTECIMENTO - MAPA. Instrução normativa № 13, de 24/03/2011. 2011. Available in: <http://sistemasweb.agricultura.gov.br/sislegis/ action/detalhaAto.do?method=consultarLegislacaoFederal>. Access in: 12/04/2017.

QUEIROZ, L. R. et al. Supressão de plantas daninhas e produção de milho-verde orgânico em sistema de plantio direto. Planta Daninha, 28(2):263-270, 2010.

RODRIGUES, E. F. da G.; DE-POLLI, H.; EIRA, P. A. da. Inoculação, calagem e adubação para mucuna-preta e feijão-deporco num solo podzólico Vermelho-Amarelo. Pesquisa Agropecuária Brasileira, 29(5):807-814, 1994.

SOARES, A. L. de L. et al. Eficiência agronômica de rizóbios selecionados e diversidade de populações nativas nodulíferas em Perdões (MG). I-caupi. Revista Brasileira de Ciência do Solo, 30(5):795-802, 2006.

SOUZA, R. A. et al. Conjunto mínimo de parâmetros para avaliação da microbiota do solo e da fixação biológica do nitrogênio pela soja. Pesquisa Agropecuária Brasileira, 43(1):83-91, 2008.

TEODORO, R. B. et al. Acúmulo de fitomassa e ciclagem de macronutrientes por leguminosas herbáceas, no município de Turmalina-MG. Revista Brasileira de Agroecologia, 4(2):1511-1514, 2009.

ZACCHEO, P. V. C. et al. Green manure in fruticulture: Aspects on soil quality and use in agriculture. African Journal of Agricultural Research, 11(17):1469-1474, 2016. 